\title{
Impacts of Zebra Mussel Veliger Control Treatments on the Survival of Water-Hardened Landlocked Fall Chinook Salmon Eggs
}

\author{
Sierra Hillard, Nathan Huysman, Michael E. Barnes \\ South Dakota Department of Game, Fish and Parks, McNenny State Fish Hatchery, Spearfish, South Dakota, USA \\ Email: mike.barnes@state.sd.us
}

How to cite this paper: Hillard, S., Huysman, N. and Barnes, M.E. (2019) Impacts of Zebra Mussel Veliger Control Treatments on the Survival of Water-Hardened Landlocked Fall Chinook Salmon Eggs. Natural Resources, 10, 115-120. https://doi.org/10.4236/nr.2019.104008

Received: March 21, 2019

Accepted: April 19, 2019

Published: April 22, 2019

Copyright ( 2019 by author(s) and Scientific Research Publishing Inc. This work is licensed under the Creative Commons Attribution International License (CC BY 4.0).

http://creativecommons.org/licenses/by/4.0/

\begin{abstract}
Several treatment options have been developed to minimize the spread of zebra mussel Dreissena polymorpha veligers (larvae) during fish transportation. However, the effect of these treatments on the survival of newly-fertilized salmonid eggs has not been evaluated. This study examined the survival of water-hardened landlocked fall Chinook salmon Oncorhynchus tshawytscha eggs after one of four different treatments: 1) Control (no chemicals), 2) 100 $\mathrm{mg} / \mathrm{L}$ formalin for two hours, 3) $750 \mathrm{mg} / \mathrm{L}$ of potassium chloride for one hour followed by $20 \mathrm{mg} / \mathrm{L}$ formalin for two hours, and 4) $750 \mathrm{mg} / \mathrm{L}$ of potassium chloride for one hour followed by $20 \mathrm{mg} / \mathrm{L}$ formalin for three hours. The 100 $\mathrm{mg} / \mathrm{L}$ formalin treatment produced complete egg mortality. Survival to hatch was not significantly different among the other three treatments. Based on these results, the use of $750 \mathrm{mg} / \mathrm{L}$ potassium chloride for one hour followed by $20 \mathrm{mg} / \mathrm{L}$ formalin for three hours is recommended when moving Chinook salmon eggs from waters potentially infested with zebra mussels to hatcheries for incubation.
\end{abstract}

\section{Keywords}

Zebra Mussel, Dreissena polymorpha, Landlocked Fall Chinook Salmon, Oncorhynchus tshawytscha

\section{Introduction}

Originally from the Black Sea and Caspian Sea in Ukraine and southwest Russia [1], zebra mussels Dreissena polymorpha are believed to have been introduced into North America from ballast water discharged into the Great Lakes in the mid-1980s [2]. Since this introduction, their range has increased dramatically to 
include at least 29 states in the USA, with an economic impact estimated to exceed $\$ 100$ million [3]. Preventing the further spread of zebra mussels is extremely important to fisheries and other natural resource managers in the USA and Canada [4]. However, nearly any activity that moves water from one location to another, such as fish stocking or activities associated with feral fish spawning, can facilitate the movement of zebra mussels or veligers (mussel larvae) [5]. In response to this concern, Edwards et al. [6] evaluated several chemical treatments for use during fish transport, and identified some that eliminated mussel veligers without harming the fish.

Lake Oahe, South Dakota, USA contains a relatively unique population of landlocked fall Chinook salmon Oncorhynchus tshawytscha. This population is maintained entirely through the spawning of feral fish from Lake Oahe, with the eggs transported to off-site hatcheries for rearing and eventual re-stocking into the lake [7]. Zebra and other Dreissena spp. mussels are currently located downstream from Lake Oahe [8] and may be located upstream as well [9], thereby potentially complicating the shipment of newly-fertilized salmon eggs from Lake Oahe to remote hatcheries with water supplies uninfected with zebra mussel larvae. Therefore, the shipment of newly-fertilized, water-hardened, salmon eggs from Lake Oahe is of concern. Although Crank and Barnes [10] showed that the Edwards [6] disinfection protocols were not harmful to rainbow trout (O. mykiss) eyed eggs, the safety of these treatments on newly-fertilized and water-hardened landlocked fall Chinook salmon eggs has not been evaluated. Thus, the objective of this study was to determine the effects of zebra mussel control treatments on landlocked fall Chinook salmon egg survival.

\section{Methods}

The experiment was conducted at McNenny State Fish Hatchery, Spearfish, South Dakota, USA using well water $\left(11^{\circ} \mathrm{C}\right.$; total hardness as $\mathrm{CaCO}_{3}, 360 \mathrm{mg} / \mathrm{L}$; alkalinity as $\mathrm{CaCO}_{3}, 210 \mathrm{mg} / \mathrm{L} ; \mathrm{pH}, 7.6$; total dissolved solids, $390 \mathrm{mg} / \mathrm{L}$ ). Landlocked fall Chinook salmon eggs were obtained from twelve female broodfish spawned at Whitlocks Spawning Station on Lake Oahe, South Dakota, using techniques described by Huysman et al. [11]. After four hours of transportation to McNenny Hatchery, the water-hardened fertilized eggs from each spawn were disinfected in $100 \mathrm{mg} / \mathrm{L}$ povidone iodine (Western Chemical, Ferndale, Washington, USA) for ten minutes and then rinsed in fresh water. After rinsing, sixty eggs were removed from each individual spawn, and placed into four replicate 9.5- $\mathrm{cm}$ diameter Petri dishes at 15 eggs/dish. Thus, a total of 48 Petri dishes and 720 eggs were used (twelve individual spawns; four dishes/spawn; each dish contained fifteen eggs).

The experimental design consisted of the following four treatments: 1) Control (no additional chemicals), 2) $100 \mathrm{mg} / \mathrm{L}$ formalin (Fisher Scientific, Chicago, Illinois, USA) for two hours, 3) $750 \mathrm{mg} / \mathrm{L}$ of potassium chloride (http://www.naturemade.com/, Henderson, Nevada, USA) for one hour followed by $20 \mathrm{mg} / \mathrm{L}$ formalin for two hours, and 4) $750 \mathrm{mg} / \mathrm{L}$ of potassium chloride for 
one hour followed by $20 \mathrm{mg} / \mathrm{L}$ formalin for three hours. Treatments 2 and 3 were conducted as described by Edwards et al. [6] for zebra mussel veliger control, while Treatment 4 modified the Edwards et al. [6] protocol to simulate the four hours of travel from the spawning station to McNenny hatchery.

The Petri dishes with eggs received their respective treatments from stock solutions. During and after chemical treatments, the Petri dishes were placed in refrigeration units and incubated at $11^{\circ} \mathrm{C}$ using the technique described previously [12]. Dead eggs were counted and removed weekly until the eyed-stage of egg development (incubation day 28), after which dead eggs and mortality were recorded daily until complete hatch.

Data was analyzed using One-way Analysis of Variance with the SPSS (24.0) statistical analysis program (Systat Software, Inc., Chicago, Illinois, USA). Tukey's post hoc multiple comparison test was conducted if significant differences were indicated by the analysis of variance. Significance was predetermined at $\mathrm{P}<$ 0.05 .

\section{Results}

Percent hatch was significantly different among the treatments $\left(\mathrm{F}_{3.44}=7.649 ; \mathrm{P}=\right.$ $0.000)$. The $100 \mathrm{mg} / \mathrm{L}$ formalin treatment produced complete egg mortality (Table 1). Mean percent survival to hatch was not significantly different among the other three treatments.

\section{Discussion}

The results indicate that only the $750 \mathrm{mg} / \mathrm{L}$ potassium chloride and $20 \mathrm{mg} / \mathrm{L}$ formalin treatments used in this study are safe for use with newly fertilized landlocked fall Chinook salmon eggs. In contrast, Crank and Barnes [10] used the same treatments with rainbow trout eggs, including $100 \mathrm{mg} / \mathrm{L}$ formalin, and did not observe any mortality. However, salmonid egg sensitivity changes throughout egg incubation [13] [14] [15] and eyed eggs, which are at a relatively advanced stage of development, were used by Crank and Barnes [10]. In contrast, this study applied the chemical treatments much earlier, at less than 24 hours after fertilization. In addition, Crank and Barnes [10] used rainbow trout eggs and this study used Chinook salmon eggs, indicating that species-specific differences in tolerance to formalin levels are also possible [16].

Table 1. Mean (SE) percent hatch of landlocked fall Chinook salmon eggs subjected to one of three zebra mussel chemical treatments or a control (no chemical treatment). Means following by different letters are significantly different $(\mathrm{P}<0.05 ; \mathrm{N}=12)$.

\begin{tabular}{cc}
\hline Treatment & Hatch (\%) \\
\hline Control (no chemicals) & $43.33(8.30) \mathrm{z}$ \\
$750 \mathrm{mg} / \mathrm{L} \mathrm{KCl}$ for 1 hour followed by $20 \mathrm{mg} / \mathrm{L}$ formalin for 2 hours & $35.00(8.88) \mathrm{z}$ \\
$750 \mathrm{mg} / \mathrm{L} \mathrm{KCl}$ for 1 hour followed by $20 \mathrm{mg} / \mathrm{L}$ formalin for 3 hours & $43.89(8.81) \mathrm{z}$ \\
$100 \mathrm{mg} / \mathrm{L}$ formalin for 2 hours & $0.00(0.00) \mathrm{y}$ \\
\hline
\end{tabular}


The egg survival observed in this study from all but the $100 \mathrm{mg} / \mathrm{L}$ formalin treatment is typical for Lake Oahe fall Chinook salmon [17] [18]. The lack of additional egg mortality from the potassium chloride and $20 \mathrm{mg} / \mathrm{L}$ formalin treatments makes either treatment acceptable for use during Chinook salmon spawning operations, should zebra mussels become present in Lake Oahe. Given the four-hour egg transport time from the reservoir to the hatcheries, treating the eggs with $750 \mathrm{mg} / \mathrm{L}$ potassium chloride for the first hour of transport followed by three hours of $20 \mathrm{mg} / \mathrm{L}$ formalin would be particularly convenient and efficient. However, the ability of this novel three-hour formalin treatment to kill zebra mussel veligers has not been confirmed, but presumably should work possibly better than, or at least as well as, the two-hour treatment successfully used by Edwards et al. [6]. Increased time of chemical exposure has been shown to impact zebra mussel survival [19].

It must be noted that this study did not evaluate the effectiveness of any of the treatment protocols on the control of zebra mussel veligers or adults during actual egg shipment. While the protocols used have been shown to be effective within specific test conditions [6] [20], changes in water temperature, water chemistry, and the density of fish or eggs may influence the ability to kill zebra mussels [21] [22] [23]. Furthermore, the Edwards et al. [6] protocols may be less effective against other invasive Dreissenids, such as quagga mussels Dreissenabugensis [22] [23].

\section{Conclusion}

The use of $750 \mathrm{mg} / \mathrm{L}$ potassium chloride for one hour followed by $20 \mathrm{mg} / \mathrm{L}$ formalin for three hours is recommended when moving water-hardened landlocked fall Chinook salmon eggs from waters potentially infested with zebra mussels to hatcheries for incubation. This treatment would maximize the potential extermination of zebra mussel veligers with no impact on salmon egg viability. The two-hour treatment of $100 \mathrm{mg} / \mathrm{L}$ formalin should be avoided because it is lethal to water-hardened landlocked fall Chinook salmon eggs.

\section{Acknowledgements}

We thank Eric Krebs and Jill Voorhees for their assistance with this project.

\section{Conflicts of Interest}

The authors declare no conflicts of interest regarding the publication of this paper.

\section{References}

[1] Ontario Ministry of Natural Resources (2005) The Potential Effects of Zebra Mussels and Other Invasive Species on Aquaculture and Relate Activities. Handbook of Fish Culture.

[2] Hebert, P.D.N., Mucaster, B.W. and Mackie, G.L. (1989) Ecological and Genetic Studies on Dreissena polymorpha (Pallas): A New Mollusc in the Great Lakes. Ca- 
nadian Journal of Fisheries and Aquatic Sciences, 46, 1587-1591. https://doi.org/10.1139/f89-202

[3] Strayer, D.L. (2009) Twenty Years of Zebra Mussels: Lessons from the Mollusk That Made Headlines. Frontiers in Ecology and the Environment, 7, 135-141. https://doi.org/10.1890/080020

[4] Zook, B. and Phillips, S. (2015) Uniform Minimum Protocols and Standards for Watercraft Interception Programs for Dreissenid Mussels in the Western United States (UMPS). In: Wong, W.H. and Gerstenberger, S.L., Eds., Biology and Management of Invasive Quagga and Zebra Mussels in the Western United States, CRC Press, Boca Raton, 175-202. https://doi.org/10.1201/b18447-19

[5] Johnson, L.E. and Carlton, J.T. (1996) Post-Establishment Spread of Large-Scale Invasions: Dispersal Mechanism of the Zebra Mussel Dreissena polymorpha. Ecology, 77, 1686-1690. https://doi.org/10.2307/2265774

[6] Edwards, W.J., Babcock-Jackson, L. and Culver, D.A. (2000) Prevention of the Spread of Zebra Mussels during Fish Hatchery and Aquaculture Activities. North American Journal of Aquaculture, 62, 229-236. https://doi.org/10.1577/1548-8454(2000)062<0229:POTSOZ>2.3.CO;2

[7] Barnes, M.E., Cordes, R.J. and Sayler, W.A. (1997) Use of Formalin during the Incubation of Eyed Eggs of Inland Fall Chinook Salmon. Progressive Fish-Culturist, 59, 303-306. https://doi.org/10.1577/1548-8640(1997)059<0303:UOFDIO >2.3.CO;2

[8] Mari, L., Bertuzzo, E., Casagrandi, R., Gatto, M., Levin, S.A., Rodriguez-Iturbe, I. and Rinaldo, A. (2011) Hydrologic Controls and Anthropogenic Drivers of the Zebra Mussel Invasion of the Mississippi-Missouri River System. Water Resources Research, 47, W03523. https://doi.org/10.1029/2010WR009920

[9] Smith, C. (2017) Invasive Mussels Found in Montana Waters. Wildlife Management Institute Outdoor News Bulletin, 71.

[10] Crank, K.M. and Barnes, M.E. (2017) Zebra Mussel Veliger Chemical Control Treatments Do Not Impact Rainbow Trout Eyed Egg Survival. International Journal of Innovative Studies in Aquatic Biology and Fisheries, 3, 15-17.

[11] Huysman, N., Bergmann, D., Nero, P., Larson J., Sabrowski, V. and Barnes, M.E. (2018) Increased Iodine Concentrations during Landlocked Fall Chinook Salmon Egg Disinfection Decrease Bacterial Numbers with No Impact on Egg Survival. North American Journal of Aquaculture, 80, 363-368. https://doi.org/10.1002/naaq.10042

[12] Neumiller, H.K., Blain, G.A. and Barnes, M.E. (2017) Incubation of Landlocked Fall Chinook Salmon Eggs in Petri Dishes. North American Journal of Aquaculture, 79, 183-186. https://doi.org/10.1080/15222055.2017.1281854

[13] Jensen, J.O.T. and Alderdice, D.F. (1983) Changes in Mechanical Shock Sensitivity of Coho Salmon (Oncorhynchus kisutch) Eggs during Incubation. Aquaculture, 32, 303-312. https://doi.org/10.1016/0044-8486(83)90227-2

[14] Alderman, D.J. (1984) The Toxicity of Iodophors to Salmonid Eggs. Aquaculture, 40, 7-16. https://doi.org/10.1016/0044-8486(84)90211-4

[15] Crisp, D.T. (1990) Some Effects of Application of Mechanical Shock at Varying Stages of Development upon the Survival and Hatching Time of British Salmonid Eggs. Hydrobiologia, 194, 57-65. https://doi.org/10.1007/BF00012112

[16] Jensen, J.O.T. and Alderdice, D.F. (1989) Comparison of Mechanical Shock Sensitivity of Eggs of Five Pacific Salmon (Oncorhynchus) Species and Steelhead Trout (Salmo gairdneri). Aquaculture, 78, 163-181. https://doi.org/10.1016/0044-8486(89)90030-6 
[17] Davis, E.A., Wong, W.H. and Harman, W.N. (2018) Toxicity of Potassium Chloride Compared to Sodium Chloride for Zebra Mussel Contamination. Journal of Aquatic Animal Health, 30, 3-12. https://doi.org/10.1002/aah.10013

[18] Barnes, M.E., Hanten, R.P., Cordes, R.J., Sayler, W.A. and Carreiro, J. (2000) Reproductive Performance of Inland Fall Chinook Salmon. North American Journal of Aquaculture, 62, 203-211. https://doi.org/10.1577/1548-8454(2000)062<0203:RPOIFC >2.3.CO;2

[19] Young, K.L., Barnes, M.E. and Kientz, J.L. (2016) Reproductive Characteristics of Landlocked Fall Chinook Salmon from Lake Oahe, South Dakota. Prairie Naturalist, 48, 79-86.

[20] Edwards, W.J., Babcock-Jackson, L. and Culver, D.A. (2002) Field Testing of Protocols to Prevent the Spread of Zebra Mussels (Dreissena polymorpha) during Fish Hatchery and Aquaculture Activities. North American Journal of Aquaculture, 64, 220-223. https://doi.org/10.1577/1548-8454(2002)064<0220:FTOPTP>2.0.CO;2

[21] Meinelt, T., Pietrock, M., Burnison, K. and Steinberg, C. (2005) Formaldehyde Toxicity Is Altered by Calcium and Organic Matter. Journal of Applied Ichthyology, 21, 121-124. https://doi.org/10.1111/j.1439-0426.2004.00617.x

[22] Sykes, C.L. (2010) Development of an Efficient Method for Removal of Quagga Mussel Veligers from Transport Tanks at Willow Beach National Fish Hatchery. Report of US Fish and Wildlife Service to Bureau of Reclamation, Boulder City, Nevada.

[23] Pucherelli, S.F., Portz, D.E., Bloom, K., Carmon, J., Brenimer, S. and Hosler, D. (2014) Quagga Mussel Contamination of Fish Haul Trucks by Fish and Development of Effective Potassium Chloride and Formalin Treatments. Journal of Applied Aquaculture, 26, 132-148. https://doi.org/10.1080/10454438.2013.873756 